\title{
Co-Composting of Algae and Effect of the Compost on Germination and Growth of Lepidium sativum
}

\author{
Izabela Michalak*, Łukasz Tuhy, Katarzyna Chojnacka \\ Department of Advanced Material Technologies, Faculty of Chemistry, \\ Wrocław University of Technology, Smoluchowskiego 25, 50-372 Wrocław, Poland
}

Received: 15 December 2015

Accepted: 15 February 2016

\begin{abstract}
In order to obtain a value-added product from the removal and processing of waste algal biomass, it is essential to elaborate on cost-effective methods of their utilization. Composting appears to be one of the methods of obtaining a natural fertilizer. This paper demonstrates the results of a study where the biomass of seaweed (Fucus sp.) has been co-composted with ecological hay, grass, sawdust, and spent mushroom substrate for three months. The utilitarian properties of the new natural products (compost and compost extract) were examined in germination tests on Lepidium sativum. Three groups were compared: the control group treated with distilled water, and two experimental groups: one treated with seaweed extract and the other fertilized with algal compost. Results showed that the addition of compost and compost extract contributed to the increase in plant length and mass. Moreover, the biomass fertilized with new products was rich in micro- and macroelements (in particular B, Fe, $\mathrm{Cu}, \mathrm{Zn}, \mathrm{Ca}, \mathrm{K}, \mathrm{S}$ ). Utilization of algal biomass for agricultural and horticultural purposes could be beneficial for environmental protection in that it might help remove waste biomass from coastal areas and from the point of view of the economy by resulting in the production of value-added natural fertilizers and biostimulants (extracts). The latter could help reduce the use of chemical fertilizers and could help to improve physicochemical properties of the soil, thus producing an enhanced seed yield.
\end{abstract}

Keywords: brown macroalgae, composting, germination tests, multielemental analysis, natural fertilizer

\section{Introduction}

Organic agriculture produces top-quality food while respecting the environment and maintaining soil fertility through the optimal use of resources. In order to minimize the quantity of nutrients used on a farm, organic agriculture promotes their recycling. In an attempt to preserve soil fertility, preference is given to organic matter over synthetic products [1]. In organic farming the microand macroorganisms provide a vast array of minerals, vitamins, and other nutrients to the crop.

Macroalgae, also known as seaweeds, are one of the most underestimated biological resources that contain bioactive compounds such as polyunsaturated fatty acids (i.e., omega-3), vitamins (B group), carotenoids, and polyphenols, as well as compounds like auxins, gibberelins and cytokinins, dietary fiber, polysaccharides, proteins, and minerals that enhance natural plant growth [2]. Due to

*e-mail: izabela.michalak@pwr.edu.pl 
eutrophication and resultant algal blooms, it is necessary to examine the methods of removing and processing algal biomass waste and to find a method for its cost-effective utilization in order to obtain value-added products [3, 4]. Eutrophication problems occur from time to time in many areas of Europe - for example the North Sea; the Danish, Norwegian, French (Normandy and Brittany), British, and Portuguese coasts; the German Bight, and the Baltic Sea. These areas show an overabundance of sea lettuce (Ulva sp., Enteromorpha sp.) and wracks (Fucus sp.), which cause recreational and olfactory nuisances [5]. For example, the brown alga Fucus vesiculosus is widely distributed in the Baltic Sea. In the coastal regions of Estonia, the overall wet biomass of this seaweed exceeds 500,000 tons [6]. According to the Irish State Agency (BIM - Bord Iascaigh Mhara), the annual harvest of Fucus serratus stands at about 200 tons (www.bim.ie).

Composting is one of the methods of biomass utilization. Compost obtained from seaweeds can find several applications, for example as an alternative to conventional fertilizers [3]. Algae applied to plants can provide a diverse array of essential nutritional and trace elements or induce disease resistance. These in turn result in improved seed germination, enhanced root growth, higher yields, earlier harvests, increased frost resistance, and reduced incidence of insect attack [7]. The enhancement of plant growth by the application of algae has been demonstrated and recognized in reference literature [8].

This study has been undertaken to develop a simple, economically feasible technique for the conversion of seaweed biomass of Fucus sp. into compost aimed at obtaining a natural fertilizer and a seaweed extract to be applied as a biostimulant for plant growth. Algal compost and extract have been characterized in terms of multielemental composition. The utilitarian properties of bio-products were examined in the germination test on garden cress (Lepidium sativum). Their effect on average stem length, weight, and elemental composition of cress was evaluated.

\section{Experimental Procedures}

\section{Composting Process}

The biomass of seaweeds Fucus sp. (2.5 kg dry mass (d.m.)) was co-composted for three months with ecological hay (1 kg d.m.), grass (1 kg d.m.), sawdust (0.5 kg d.m.), and spent mushroom substrate, or SMS (2.5 kg wet biomass (w.m.) - humidity 65.3\%), in order to obtain an appropriate $\mathrm{C}: \mathrm{N}$ ratio (25:1-30:1 [4]).

Fucus sp., (a mix of species), a commercially available microalgae, was obtained from the FLOS Department Confectioning Herbs, Poland (www.flos.pl/en). Dry ecological hay and sawdust were purchased from a pet shop. Grass, after collection, was air-dried to constant weight. SMS was provided by GRUPA HAJDUK sp. z o.o. (www.hajduk.pl/uk).
The composting of seaweeds was conducted on the laboratory scale in a composting bin, with the total mass of the composting mixture standing at $7.5 \mathrm{~kg}$. The process was performed under controlled conditions of temperature, humidity, and aeration provided by a systematic overturning of the biomass every two days. The temperature was recorded during the composting process. The composting mixture was watered in order to provide appropriate humidity of about $70 \%$. We determined the chemical characteristics of the final compost.

\section{Production of Extract from Compost}

We produced extract from the obtained compost according to the procedure described by Alvarado et al. (2008) [9]. Subsequently, $500 \mathrm{~g}$ of the compost was filtered using a funnel with filter paper and $300 \mathrm{~mL}$ of distilled water. The filtered liquid was then added to the compost mass until an intense brown colour liquid appeared (the solution was recycled three times). The filtration lasted for about two hours.

\section{Evaluation of Compost $\mathrm{pH}$}

The sample of air-dried compost was ground in a mortar. In a beaker, $2 \mathrm{~g}$ of powdered compost was mixed with $25 \mathrm{~mL}$ of $1 \mathrm{M} \mathrm{KCl}$. The content of the beaker was thoroughly mixed with a glass rod and left for 24 hours. Thereafter, again the content of the beaker was thoroughly mixed and the $\mathrm{pH}$ was measured using a Mettler-Toledo pH meter (Seven Multi, Greifensee, Switzerland) equipped with an InLab413 electrode [10].

\section{Germination Tests}

The utilitarian properties of the new natural products (i.e., compost and algal compost extract) were examined using germination tests on Lepidium sativum. Three groups were compared: the control group watered with distilled water and two experimental groups: one watered with seaweed extract and the other fertilized with dry algal compost. Germination tests were performed according to the international norm (International Rules for Seed Testing 2011, International Seed Testing Association). Plastic Petri dishes (diameter $85 \mathrm{~mm}$ ) with cotton (approximately $5 \mathrm{~g}$ ) soaked in deionized water were prepared. On each dish, 50 seeds were placed in rows at equal distances from each other. Seeds were subjected to three-day stratification at $1^{\circ} \mathrm{C}$. After stratification, $1 \mathrm{~g}$ of dried compost was applied to the Petri dish. Every day it was watered with $2 \mathrm{~mL}$ distilled water. In the second experimental group, seeds were watered every day with the application of $2 \mathrm{~mL}$ of algal compost extract. In the control group, seeds were treated every day with $2 \mathrm{~mL}$ of distilled water. Each experiment was performed in three replicates. After the germination tests, the length of 20 randomly selected plants was measured. Dry mass of Lepidium sativum in each group was weighed. Also, the content of micro- and macronutrients in the germinated plants was determined. 


\section{Analytical Methods}

Biological samples (i.e., each ingredient of the composting mixture, prepared composting mixture, final compost, plants after germination tests) (ca. $0.5 \mathrm{~g}$ ) were digested in $69 \% \mathrm{~m} \mathrm{~m}^{-1}(5 \mathrm{~mL})$ spectrally pure (Suprapur, Merck) concentrated nitric acid, in Teflon bombs in a Milestone Start D microwave oven (USA). The selected parameters of the process assured the complete digestion of samples $\left(\mathrm{T}_{1} 200^{\circ} \mathrm{C}, p 45\right.$ bar, 15 minutes, $1200 \mathrm{~W}$; $\mathrm{T}_{2} 110^{\circ} \mathrm{C}, p 45$ bar, 15 minutes, $1200 \mathrm{~W}$; Milestone, application book).

After mineralization, samples were diluted with re-demineralized water (Millipore Simplicity). Total sample weight was $50 \mathrm{~g}$. Mineralized samples underwent multielemental analysis. The concentration of elements in digested biomass and in solution of the extract was determined by ICP-OES iCAP 6500 Duo, Thermo Scientific, USA. The analyses (mineralization and ICPOES) were carried out in a quality management system according to PN-EN ISO/IEC 17025:2005. Quality assurance of the test results was achieved using Combined Quality Control Standard from ULTRA SCIENTIFIC, USA. The samples were analyzed in three repeats (the reported results of analyses were an arithmetic mean; the relative standard deviation was $<5 \%$ ). The content of nitrogen and carbon in each ingredient of the compost, composting mixture, and final compost was measured with a Vario MACRO Cube $\mathrm{CN}$ analyzer (Elementar Analysensysteme GmbH, Germany).

\section{Statistical Methods}

The results were elaborated upon statistically by Statistica ver. 10. Normality of distribution of experimental results was assessed by the Shapiro-Wilk test. On this basis, a statistical test was selected for investigating the significance of the differences between the groups. For normal distribution, the differences between the groups were investigated with a one-way analysis of variance (ANOVA) using the Tukey test. If the distribution was not normal, the Kruskal-Wallis test was applied. Results were considered significantly different when $p<0.05$.

\section{Results and Discussion}

In reference literature, the composting process of algae is used to either produce amendment/natural fertilizers for enhancing physical and nutritional characteristics of local soils used in intensive horticulture or to find a way to reduce environmental pollution $[11,12]$.

\section{Algae Composting Process}

Before decomposition can set in, the composted materials must have an appropriate $\mathrm{C} / \mathrm{N}$ ratio that permits microbial activity, which should be between 25:1 and 30:1 [4]. The content of $\mathrm{C}$ and $\mathrm{N}$ in the composting mixture with a humidity of $69.7 \%$ was $45.2 \%$ and $1.84 \%$ (dry mass), respectively. The ratio of $\mathrm{C}: \mathrm{N}$ in the composting mixture was 24.5:1. In the final compost the content of $\mathrm{C}$ and $\mathrm{N}$ in dry mass (with the ratio of 13.8 ) were $32.0 \%$ and N 2.32\%, respectively. In the work by Eyras et al. (1998), the initial (in algae plus sawdust) $\mathrm{C} / \mathrm{N}$ ratio was 26.0 ; after composting, this value decreased down to 11.2. This was indicated by high microbial activity during the process and good biological stabilization [11].

During the thermophilic phase of the composting process, the temperature reached up to $50^{\circ} \mathrm{C}$ and stayed so for three weeks. After day 90 , the temperature dropped and stood at ambient levels, i.e., $36^{\circ} \mathrm{C}$. Moisture content was maintained at above $50 \%$. The $\mathrm{pH}$ of the obtained compost was 7.55 , which is similar to the $\mathrm{pH}$ values of compost obtained by other authors [7, 9, 13-17]. The $\mathrm{pH}$ of the extract obtained from the compost was 8.18.

\section{Multielemental Composition of the Algal Bio-Products}

The multielemental composition of the compost ingredients was determined by the ICP-OES method and is presented in Table 1. As raw materials for composting, Fucus sp. can provide micro- and macroelements in concentrations that are considered adequate for enhanced plant growth and development. The biomass of Fucus sp. was a rich source of $\mathrm{K}, \mathrm{Mg}, \mathrm{S}$, and $\mathrm{B}$. Spent mushroom substrate, which was rich in micro- and macroelements $(\mathrm{Cu}, \mathrm{Fe}, \mathrm{Mo}, \mathrm{Zn}, \mathrm{Ca}$, and $\mathrm{P})$, was the second component of compost. This component is known to improve soil structure and quality and to enhance nutrient intake [18].

Table 2 shows the composition of the initial composting mixture, final compost, and algal extract. During the composting process, there was an increase in the content of $\mathrm{Ca}, \mathrm{Mg}, \mathrm{P}$, and $\mathrm{S}$ in the obtained compost. According to Faridullah et al. (2014) such an increase might be due to the concentration effect as compost volume decreased with time [19]. Not only did the content of macronutrient increase in the final compost; the same effect was also observed for micronutrients $(\mathrm{Cu}, \mathrm{Fe}, \mathrm{Mn}$, $\mathrm{Ni}, \mathrm{Zn}$ ). The levels of toxic metals in the obtained compost were very low with respect to the limits established by Polish legislation (Journal of Laws from 2008, No. 110, item 765), as well as by Regulation No. 2003/2003 of the European Parliament and of the Council of 13 October 2003 relating to fertilizers. The acceptable levels of toxic elements are as follows: $\mathrm{Cr}<100 \mathrm{mg} / \mathrm{kg} \mathrm{d.m}$., $\mathrm{Cd}<5 \mathrm{mg} / \mathrm{kg}$ d.m., $\mathrm{Ni}<60 \mathrm{mg} / \mathrm{kg}$ d.m., $\mathrm{Pb}<140 \mathrm{mg} / \mathrm{kg}$ d.m.

The mineral composition of the final product is rarely investigated in the reference literature. The content of macroelements in the obtained final compost from Fucus sp. was compared with other algae-based composts (Table $3)$. In the final compost, carbon content ranged from $48.0 \%$ (fish, seaweed, pine bark) [1] to $6.15 \%$ (seaweed and sawdust [16]), and in this study $32 \%$. Nitrogen and potassium content were highest in the compost prepared only from Sargassum seaweed $(2.43 \%$ and $9.05 \%$, 
Table 1. Multielemental composition of the compost ingredients.

\begin{tabular}{|c|c|c|c|c|c|c|c|}
\hline \multirow{2}{*}{\multicolumn{2}{|c|}{ Element }} & Wave-length & Fucus sp. & Ecological hay & Grass & \multirow{2}{*}{$\begin{array}{c}\text { Sawdust } \\
\mathrm{mg} / \mathrm{kg} \text { w.m. }\end{array}$} & SMS \\
\hline & & $\mathrm{nm}$ & \multicolumn{3}{|c|}{ mg/kg d.m. } & & \\
\hline \multirow{5}{*}{$\begin{array}{l}\text { Macro- } \\
\text { elements }\end{array}$} & $\mathrm{Ca}$ & 315.887 & $13,100 \pm 2,620$ & $4,750 \pm 950$ & $6,860 \pm 1,370$ & $1,820 \pm 370$ & $37,760 \pm 7,550$ \\
\hline & $\mathrm{K}$ & 766.490 & $43,900 \pm 8,780$ & $3,130 \pm 630$ & $31,040 \pm 6210$ & $380 \pm 60$ & $2,930 \pm 590$ \\
\hline & $\mathrm{Mg}$ & 285.213 & $8,050 \pm 6,110$ & $1,730 \pm 350$ & $2,300 \pm 460$ & $450 \pm 70$ & $1,520 \pm 300$ \\
\hline & $\mathrm{P}$ & 213.618 & $920 \pm 140$ & $1,610 \pm 320$ & $3,620 \pm 720$ & $69.0 \pm 10.0$ & $1,960 \pm 390$ \\
\hline & $\mathrm{S}$ & 182.034 & $17,540 \pm 3,510$ & $1,380 \pm 280$ & $3120 \pm 620$ & $86.0 \pm 13.0$ & $11,040 \pm 2,210$ \\
\hline \multirow{7}{*}{$\begin{array}{l}\text { Micro- } \\
\text { elements }\end{array}$} & B & 249.773 & $74.0 \pm 11.0$ & $3.00 \pm 0.40$ & $5.50 \pm 0.80$ & $<$ LLD & $7.90 \pm 1.20$ \\
\hline & $\mathrm{Cu}$ & 324.754 & $2.35 \pm 0.35$ & $8.00 \pm 1.20$ & $12.0 \pm 2.0$ & $2.50 \pm 0.40$ & $14.0 \pm 2.0$ \\
\hline & $\mathrm{Fe}$ & 259.940 & $400 \pm 60$ & $240 \pm 40$ & $390 \pm 60$ & $44.0 \pm 7.0$ & $2,690 \pm 540$ \\
\hline & $\mathrm{Mn}$ & 257.610 & $66.0 \pm 10.0$ & $340 \pm 50$ & $96.0 \pm 14.0$ & $95.0 \pm 14.0$ & $120 \pm 20$ \\
\hline & Mo & 202.030 & $0.490 \pm 0.070$ & $0.200 \pm 0.030$ & $0.590 \pm 0.090$ & $0.0920 \pm 0.0230$ & $0.580 \pm 0.090$ \\
\hline & $\mathrm{Ni}$ & 231.604 & $2.90 \pm 0.40$ & $1.50 \pm 0.20$ & $2.10 \pm 0.30$ & $0.560 \pm 0.085$ & $2.50 \pm 0.40$ \\
\hline & $\mathrm{Zn}$ & 213.856 & $36.0 \pm 5.0$ & $40.0 \pm 6.0$ & $35.0 \pm 5.0$ & $23.0 \pm 3.0$ & $66.0 \pm 10.0$ \\
\hline \multirow{5}{*}{$\begin{array}{c}\text { Other } \\
\text { elements }\end{array}$} & $\mathrm{Al}$ & 308.215 & $200 \pm 30$ & $29.0 \pm 4.0$ & $320 \pm 50$ & $17.0 \pm 3.0$ & $1490 \pm 300$ \\
\hline & Co & 228.616 & $0.450 \pm 0.070$ & $0.0560 \pm 0.0140$ & $0.260 \pm 0.040$ & $0.0370 \pm 0.0090$ & $0.610 \pm 0.090$ \\
\hline & $\mathrm{Cr}$ & 267.716 & $1.60 \pm 0.20$ & $1.605 \pm 0.20$ & $2.20 \pm 0.30$ & $1.10 \pm 0.20$ & $3.60 \pm 0.50$ \\
\hline & $\mathrm{Na}$ & 589.592 & $35150 \pm 7030$ & $340 \pm 50$ & $620 \pm 90$ & $260 \pm 40$ & $540 \pm 80$ \\
\hline & V & 290.882 & $1.40 \pm 0.20$ & $0.710 \pm 0.110$ & $1.70 \pm 0.25$ & $0.590 \pm 0.090$ & $3.60 \pm 0.50$ \\
\hline \multirow{3}{*}{$\begin{array}{c}\text { Toxic } \\
\text { elements }\end{array}$} & As & 189.042 & $20.0 \pm 3.0$ & $0.0780 \pm 0.0160$ & $0.0760 \pm 0.0150$ & $<$ LLD & $1.90 \pm 0.20$ \\
\hline & $\mathrm{Cd}$ & 228.802 & $0.970 \pm 0.130$ & $0.170 \pm 0.020$ & $0.140 \pm 0.020$ & $0.530 \pm 0.070$ & $0.150 \pm 0.020$ \\
\hline & $\mathrm{Pb}$ & 220.353 & $0.970 \pm 0.130$ & $1.20 \pm 0.20$ & $2.10 \pm 0.30$ & $0.770 \pm 0.100$ & $2.90 \pm 0.40$ \\
\hline
\end{tabular}

$<$ LLD below low limit of detection; for As $0.0045 \mathrm{mg} / \mathrm{kg}$; B $0.0076 \mathrm{mg} / \mathrm{kg}$.

respectively [9]) and the lowest in the compost from seaweed and sawdust $(0.41 \%$ and $0.37 \%$, respectively [16]; in this study N 2.32\%, K 2.84\%. Phosphorus content ranged from 0.63 [1] to $0.11 \%$ [7]. Data comparisons indicated that the compost with seaweeds examined in the present study gave a relatively high percentage of NPK compared to other composts. According to the Polish Act on Fertilizers and Fertilization and the Regulation of the Minister of Agriculture and Rural Development in Poland of 18 June 2008 (Journal of Laws No. 119, item. 765), solid organic fertilizers should contain at least $30 \%$ of organic matter based on dry matter, $0.3 \%\left(\mathrm{~m} \mathrm{~m}^{-1}\right)$ of total nitrogen, $0.2 \%\left(\mathrm{~m} \mathrm{~m}^{-1}\right)$ of phosphorus based on phosphorus pentoxide $\left(\mathrm{P}_{2} \mathrm{O}_{5}\right)$, and $0.2 \%$ of potassium based on potassium oxide $\left(\mathrm{K}_{2} \mathrm{O}\right)$. The algal compost obtained in the present study fulfills these recommendations.

It should be emphasized that seaweed composting entails some problems that should be solved before the compost is used as an amendment. The main disadvantages of algae compost are salinity and heavy metals content [20]. In the present paper it was shown that the composting mixture contained a large amount of sodium at $16,300 \mathrm{mg} \mathrm{kg}^{-1}$ (probably due to high sodium content in the seaweed mix). After three months this content was reduced by $18 \%$. Tang et al. (2011) suggested that this problem can be solved by diluting algal compost with other raw materials, or by applying the compost during a period when plant growth is less affected by the salt present in the compost [21].

As can be seen from Table 3, the primary substrate (the main waste material that requires treatment, in this case macroalgae) was enriched with different amendments (material that balances the $\mathrm{C} / \mathrm{N}$ ratio, modifies the $\mathrm{pH}$, improves stability, and achieves the proper moisture content) and bulking agents (material that provides structure and porosity to the pile and helps maintain aerobic conditions in the compost pile, i.e., sawdust and straw) [22]. Straw [13, 15], bark [1, 14, 16], sawdust [this study, 16], and green wastes [this study, 7, 17] are examples of materials that are the most often added to the composting mixtures of algae as bulking agents.

\section{Utilitarian Properties of the Compost and Extract}

After the composting process, utilitarian properties of the obtained fertilizer and compost extract were 
Table 2. Multielemental composition of initial composting mixture, obtained compost, and algal extract.

\begin{tabular}{|c|c|c|c|c|c|}
\hline \multirow{2}{*}{ Element } & \multirow{2}{*}{$\begin{array}{l}\text { Wavelength } \\
(\mathrm{nm})\end{array}$} & \multicolumn{2}{|c|}{ Composting mixture } & \multirow{2}{*}{$\begin{array}{c}\text { Final compost } \\
\mathrm{mg} / \mathrm{L} \\
\end{array}$} & \multirow{2}{*}{$\begin{array}{c}\text { Extract from algal } \\
\text { compost }\end{array}$} \\
\hline & & & kg d.m. & & \\
\hline \multirow{5}{*}{ Macronutrients } & $\mathrm{Ca}$ & 315.887 & $22,300 \pm 4,500$ & $44,500 \pm 8,900$ & $729 \pm 109$ \\
\hline & $\mathrm{K}$ & 766.490 & $30,400 \pm 6,100$ & $28,400 \pm 5,700$ & $4,600 \pm 920$ \\
\hline & $\mathrm{Mg}$ & 285.213 & $4,840 \pm 970$ & $6,570 \pm 1,320$ & $427 \pm 64.0$ \\
\hline & $\mathrm{P}$ & 213.618 & $1,770 \pm 350$ & $2,830 \pm 570$ & $593 \pm 88.9$ \\
\hline & $\mathrm{S}$ & 182.034 & $11,500 \pm 2,300$ & $23,000 \pm 4,600$ & $1,750 \pm 350$ \\
\hline \multirow{7}{*}{ Micronutrients } & $\mathrm{B}$ & 249.773 & $133 \pm 20$ & $96.9 \pm 14.5$ & $0.486 \pm 0.073$ \\
\hline & $\mathrm{Cu}$ & 324.754 & $13.9 \pm 2.1$ & $15.3 \pm 2.3$ & $0.267 \pm 0.040$ \\
\hline & $\mathrm{Fe}$ & 259.940 & $1,120 \pm 230$ & $2,740 \pm 550$ & $2.24 \pm 0.34$ \\
\hline & $\mathrm{Mn}$ & 257.610 & $168 \pm 25$ & $192 \pm 29$ & $1.04 \pm 0.16$ \\
\hline & Mo & 202.030 & $<\mathrm{LLD}$ & $<\mathrm{LLD}$ & $<\mathrm{LLD}$ \\
\hline & $\mathrm{Ni}$ & 231.604 & $0.612 \pm 0.092$ & $9.09 \pm 1.36$ & $<\mathrm{LLD}$ \\
\hline & $\mathrm{Zn}$ & 213.856 & $55.8 \pm 8.4$ & $98.5 \pm 14.8$ & $0.413 \pm 0.062$ \\
\hline \multirow{5}{*}{ Other elements } & $\mathrm{Al}$ & 308.215 & $496 \pm 74$ & $1760 \pm 350$ & $6.57 \pm 0.98$ \\
\hline & Co & 228.616 & $<\mathrm{LLD}$ & $2.92 \pm 0.44$ & $0.568 \pm 0.085$ \\
\hline & $\mathrm{Cr}$ & 267.716 & $3.70 \pm 0.55$ & $4.39 \pm 0.66$ & $<\mathrm{LLD}$ \\
\hline & $\mathrm{Na}$ & 589.592 & $16,300 \pm 3300$ & $13,800 \pm 2800$ & $2,470 \pm 500$ \\
\hline & $\mathrm{V}$ & 290.882 & $15.5 \pm 2.3$ & $36.5 \pm 5.5$ & $1.05 \pm 0.16$ \\
\hline \multirow{2}{*}{ Toxic elements } & $\mathrm{Cd}$ & 228.802 & $0.254 \pm 0.033$ & $0.533 \pm 0.069$ & $<\mathrm{LLD}$ \\
\hline & $\mathrm{Pb}$ & 220.353 & $9.95 \pm 1.29$ & $<$ LLD & $<$ LLD \\
\hline
\end{tabular}

$<$ LLD below low limit of detection; for Co $0.0012 \mathrm{mg} / \mathrm{kg}$; Cr $0.0010 \mathrm{mg} / \mathrm{kg}$; Mo $0.0026 \mathrm{mg} / \mathrm{kg}$; Ni $0.0028 \mathrm{mg} / \mathrm{kg}$; Pb $0.0060 \mathrm{mg} / \mathrm{kg}$.

examined in germination tests on Lepidium sativum (Fig. 1). Reference literature provides us with confirmation that algal compost has a positive effect on plant cultivation. For example, it was observed that seaweed compost (a) showed seed germination of Zea mays increase by 78\% [12], (b) improved vegetative growth and yield of cucumber plants [23], (c) increased water-holding capacity of tomatoes and enhanced growth for Licopersicum esculentum var. platense [11], (d) caused faster specific growth rate for the edible radish (Raphanus sativus) while increasing the number of leaves [7]. The germination index of Lactuca sativa seeds in the compost (made from fish waste and seaweed) was $81.1 \%$, which indicated the absence of phytotoxic substances or their presence at very low levels [1].

Table 4 presents mineral composition of the cultivated Lepidium sativum. Statistically significant differences $(p<0.05)$ were determined for $\mathrm{Ca}, \mathrm{Cu}, \mathrm{K}, \mathrm{Mn}, \mathrm{Mg} \mathrm{Na}, \mathrm{P}$, $\mathrm{S}, \mathrm{Si}$, and $\mathrm{V}$. An increase in the macroelements content in plant material was observed mainly after the application of compost extract (beside P). For example, Lepidium sativum from the group with the extract contained by $40 \%$ more of $\mathrm{Mg}, 51 \%$ of $\mathrm{Na}, 72 \%$ of S, ca. 2.5 times more of $\mathrm{Ca}$, and three times more of $\mathrm{K}$ than Lepidium sativum from the control group. Sosnowski et al. (2014) have also shown that the application of the extract from Ecklonia maxima increased the content of macroelements (especially $\mathrm{K}$ by $16 \%$ higher than in the control group) in aerial biomass of hybrid alfalfa. It has also been shown that algal extract increased the content of $\mathrm{Zn}$ in the biomass and decreased the content of $\mathrm{Cu}$ [24]. The same phenomenon was observed in the experiment presented here. It is indicated that the micronutrients $(\mathrm{Cu}, \mathrm{Mn}, \mathrm{Zn}$, and $\mathrm{Fe})$ are divalent cations in their soluble, plant available forms and that they are antagonistic toward each other [25].

Taking into account the content of microelements in the biomass as a criterion, algal compost highly influenced their content in Lepidium sativum. The highest increase was observed in the case of boron at 3.6 times, then for $\mathrm{Fe}$ (2 times), Mn (28\%), and $\mathrm{Zn}(11 \%)$. Boron is a trace element that is provided by seaweed biomass (73.8 $\mathrm{mg} \mathrm{kg}^{-1}$ d.m.). The content of elements such as Mo, $\mathrm{Ni}, \mathrm{Co}, \mathrm{Cr}, \mathrm{Cd}$, and $\mathrm{Pb}$ in the plants from all groups was below detection limits.

It was also found that the Lepidium sativum cultivated in the group with compost contained a high amount of aluminum at $123 \mathrm{mg} \mathrm{kg}^{-1} \mathrm{~d}$.m. - six times higher than in the control group and seven times higher than in the group with compost extract, which results from the composition of the final compost and extract. Aluminum was extracted 
Table 3. The content of the main macronutrients in final algal compost (\%) reported in the literature.

\begin{tabular}{|c|c|c|c|c|c|c|c|c|}
\hline \multirow{2}{*}{ Composting material } & \multicolumn{7}{|c|}{ Content of the main macronutrients in final algal compost (\%) } & \multirow{2}{*}{ Ref. } \\
\hline & $\mathrm{C}$ & $\mathrm{N}$ & $\mathrm{P}$ & $\mathrm{K}$ & $\mathrm{Na}$ & $\mathrm{Ca}$ & $\mathrm{Mg}$ & \\
\hline $\begin{array}{l}\text { Sargassum filipendula, S. filipendula, S. furcatum, } \\
\text { S. rigidulum, S. vulgare }(99 \%)\end{array}$ & ND & 2.43 & 0.42 & 9.05 & ND & 3.67 & 1.22 & 12 \\
\hline Ulva rigida $(90 \%)$ and straw $(10 \%)$ & 21.0 & 1.71 & 0.183 & 0.967 & 1.12 & 2.93 & 2.52 & 13 \\
\hline $\begin{array}{l}20 \% \text { seaweed (Laminaria spp. } \\
\text { and Cystoseira spp.), } \\
20 \% \text { fish waste and } 60 \% \text { pine bark }\end{array}$ & 47.4 & 2.16 & 0.57 & 0.74 & 1.03 & 0.80 & 0.26 & 14 \\
\hline $\begin{array}{c}\text { Fish, seaweed (Laminaria sp. and Cystoseira } \mathrm{sp} .) \\
\text { and pine bark }(1: 1: 3)\end{array}$ & 48.0 & 2.13 & 0.63 & 0.69 & 1.19 & 0.44 & 0.25 & 1 \\
\hline Ulva sp. (65\%) and poplar bark & 9.66 & 0.69 & 0.28 & 0.54 & 1.5 & 11.2 & 0.51 & 16 \\
\hline Ulva sp. $(82 \%)$ and poplar sawdust & 6.15 & 0.41 & 0.15 & 0.37 & 1.9 & 15.4 & 0.49 & 16 \\
\hline $\begin{array}{c}\text { Mediterranean seagrass and seaweed residues } \\
\text { with yard waste }\end{array}$ & 30.8 & 0.91 & 0.079 & 0.83 & ND & 8.03 & 7.5 & 17 \\
\hline $\begin{array}{l}\text { Ulva sp. }(28 \%), \text { straw/ipomoea }(54 \%) \\
\text { cow manure }(18 \%)\end{array}$ & ND & 0.85 & 0.619 & 0.822 & ND & ND & ND & 15 \\
\hline $\begin{array}{l}\text { Microdictyon umbilicatum (20\%) with the shredded } \\
\text { green waste }\end{array}$ & 21.3 & 0.82 & 0.11 & 0.45 & 0.31 & 1.35 & 0.28 & 7 \\
\hline $\begin{array}{l}\text { Fucus sp. (ca. 35\%), SMS (ca. 35\%) ecological hay } \\
\text { (ca. } 12.5 \% \text { ), grass (ca. } 12.5 \% \text { ), sawdust (ca. } 5 \% \text { ) }\end{array}$ & 32.0 & 2.32 & 0.283 & 2.84 & 1.38 & 4.45 & 0.657 & This study \\
\hline
\end{tabular}

ND - no data

from the compost only to a small extent. The content of Al in the edible garden cress was comparable to that in other vegetables, for example in spinach at $104 \mathrm{mg} \mathrm{kg}^{-1} \mathrm{~d} . \mathrm{m}$. and lettuce leaves at $73 \mathrm{mg} \mathrm{kg}^{-1} \mathrm{~d} . \mathrm{m}$. [26].

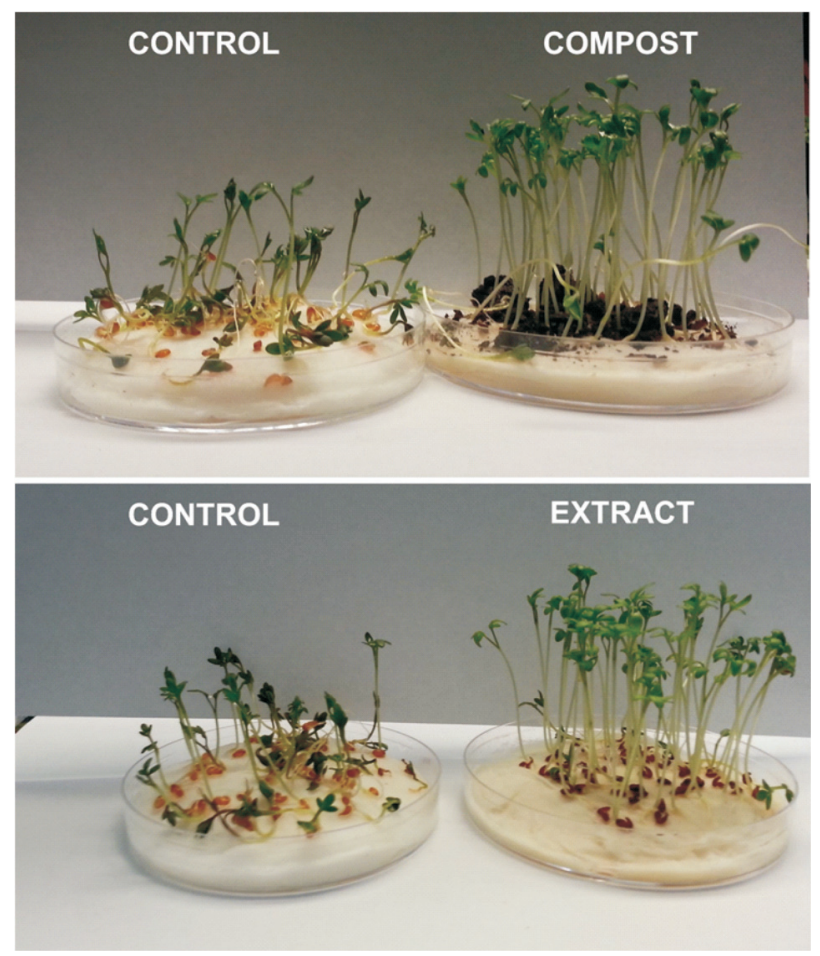

Fig. 1. Germination tests on Lepidium sativum - a comparison of experimental groups (after seven days).
In the case of sodium, its content in Lepidium sativum was comparable to that of the control and compost groups. The highest amount was observed in the group where extract was applied, and it was $34 \%$ higher than in the control group. It is assumed that the intake of this element by plants was higher from extract than from compost. Algal-based extracts are known to contain chelators of metal ions that help to transport elements into the plant and to make them more bioavailable [27].

We also observed that the average stem length (from four replicates) of plants fertilized with the compost $(5.56 \pm 0.11 \mathrm{~cm})$ and the extract $(5.45 \pm 0.34 \mathrm{~cm})$ was almost twice as high as that in the control group $(3.01 \pm 0.80 \mathrm{~cm})$. The weight of wet biomass was also higher in both experimental groups (compost $1.49 \pm 0.06 \mathrm{~g}$, extract $1.43 \pm 0.12 \mathrm{~g})$ than in the control group $(0.812 \pm 0.309 \mathrm{~g})$. For compost it was $83 \%$ and for extract $76 \%$ higher than for the control. Dry mass of the cultivated plants was as follows: control $0.054 \pm 0.013 \mathrm{~g}$, compost $0.059 \pm 0.008 \mathrm{~g}$, extract $0.074 \pm 0.004 \mathrm{~g}$. On the basis of the obtained results we could conclude that algal compost could improve vegetative growth and yield of plants. The observations obtained in this work were confirmed by Ahmed and Shalaby (2012) [23]. It was shown that algal extracts prepared from red algae (Asparagopsis spp., Gelidium pectinutum) and green algae (Enteromorpha intestinelis) influenced such growth parameters of cucumber plants (Cucumis sativus L.) as plant height, number of leaves, plant fresh weight, plant dry weight, and leaf area to a higher extent as compared to the application of compost (organic manure) [23]. Haq et al. (2011) showed that the efficacy of seaweed compost was comparable to that of 
Table 4. Mineral composition of germinated Lepidium sativum.

\begin{tabular}{|c|c|c|c|c|c|}
\hline \multirow{2}{*}{\multicolumn{2}{|c|}{ Element }} & Wavelength & Control group & Compost group & \multirow{2}{*}{ Extract group } \\
\hline & & \multirow{2}{*}{$\begin{array}{c}\mathrm{nm} \\
315.887\end{array}$} & \multicolumn{2}{|c|}{$\mathrm{mg} / \mathrm{kg}$ d.m. $(\mathrm{N}=3)$} & \\
\hline \multirow{5}{*}{ Macro-nutrients } & $\mathrm{Ca}$ & & $2,460 \pm 490^{\mathrm{a}, \mathrm{b}}$ & $6,100 \pm 1,200^{\mathrm{a}}$ & $6,200 \pm 1,200^{\mathrm{b}}$ \\
\hline & K & 766.490 & $15,500 \pm 3,100^{\mathrm{a}, \mathrm{b}}$ & $47,900 \pm 9,600^{\mathrm{a}}$ & $48,500 \pm 9,700^{\mathrm{b}}$ \\
\hline & $\mathrm{Mg}$ & 285.213 & $5,620 \pm 1,120^{\mathrm{a}}$ & $6,960 \pm 1,390$ & $7,860 \pm 1,570^{\mathrm{a}}$ \\
\hline & $\mathrm{P}$ & 213.618 & $8,920 \pm 1,780^{\mathrm{a}}$ & $8,070 \pm 1,610$ & $7,490 \pm 1,500^{\mathrm{a}}$ \\
\hline & S & 182.034 & $11,600 \pm 2,300^{\mathrm{a}}$ & $16,900 \pm 3,400$ & $19,900 \pm 4,000^{\mathrm{a}}$ \\
\hline \multirow{5}{*}{ Micro-nutrients } & B & 249.773 & $6.95 \pm 1.04$ & $25.3 \pm 3.8$ & $16.5 \pm 2.5$ \\
\hline & $\mathrm{Cu}$ & 324.754 & $13.1 \pm 2.0^{\mathrm{a}, \mathrm{b}}$ & $9.61 \pm 1.44^{\mathrm{a}}$ & $8.20 \pm 1.23^{\mathrm{b}}$ \\
\hline & $\mathrm{Fe}$ & 259.940 & $131 \pm 20$ & $257 \pm 38$ & $125 \pm 19$ \\
\hline & $\mathrm{Mn}$ & 257.610 & $42.3 \pm 6.3^{\mathrm{a}}$ & $54.0 \pm 8.1^{\mathrm{a}, \mathrm{b}}$ & $38.6 \pm 5.8^{\mathrm{b}}$ \\
\hline & $\mathrm{Zn}$ & 213.856 & $153 \pm 23$ & $171 \pm 26$ & $162 \pm 24$ \\
\hline \multirow{3}{*}{ Other elements } & $\mathrm{Al}$ & 308.215 & $20.1 \pm 3.0$ & $123 \pm 18$ & $17.3 \pm 2.6$ \\
\hline & $\mathrm{Na}$ & 589.592 & $10,700 \pm 2100^{\mathrm{a}}$ & $9,580 \pm 1,920^{\mathrm{b}}$ & $16,200 \pm 3,200^{\mathrm{a}, \mathrm{b}}$ \\
\hline & V & 290.882 & $18.8 \pm 2.8^{\mathrm{a}}$ & $23.1 \pm 3.5^{\mathrm{b}}$ & $28.1 \pm 4.2^{\mathrm{a}, \mathrm{b}}$ \\
\hline
\end{tabular}

a, $\mathrm{b}$ for $p<0.05$ - statistically significant differences.

Test RIR Tukey was used for $\mathrm{Ca}, \mathrm{Cu}, \mathrm{K}, \mathrm{Mn}, \mathrm{Na}, \mathrm{V}$; Kruskal-Wallis test was used for Mg, P, S, Si.

the commercial product (Biogold organic compost). The percentages of Zea mays seed germination were 75 and $85 \%$, respectively, which are higher than for cow dung $(60 \%)$. Data comparisons also indicated that seaweed compost gave a relatively high percentage of NPK [12]. The application of compost in agriculture is a way to reduce environmental pollution, with the bioavailability of macro- and micronutrients to plants from compost being higher than from synthetic fertilizers [28].

\section{Practical, Environmental, and Economic Implications of our Research}

Although algae is an environmental problem around the world, composting it on a large scale is rarely discussed. Nowadays from an economic point of view, it is not desirable to increase the load of organic waste in landfills. Therefore, there is a need to evaluate the use of algal bloom biomass as an agricultural compost conditioner for native and commercial plants [7]. Now, algae are used as raw fertilizer in some sites close to the sea or, for a small part, they are brought to areas of household waste treatment [29]. Few researchers have been dealing with controlled composting of algae. These are of the opinion that various composting technologies for algae stabilization can be used, for example piles $[1,7,11,12,13-16,30]$, which can be loaded with up to 25 tons of algae [16] and can have a size of, for example, $6 \times 2 \times 1.5 \mathrm{~m}$ [14]. It is beneficial to create piles from algal biomass near the place of their discharge [14]. In a review paper, Han et al. (2014) emphasize that although composting has been successfully used on a pilot scale to manage algae waste removed from eutrophied water environments, and the compost product has been applied as a fertilizer, clear guidelines for full-scale algae composting are not yet available. Another option is algae composting in a vessel system, for example in thermos bottles [31], reactors [32], or plastic containers [9] whose volumes range from $500 \mathrm{~mL}$ [31] to $300 \mathrm{~L}$ [32].

In conclusion, the composting of waste algal biomass using the techniques described above can be treated as an environmental "must," to use a phrase coined by Charlier et al. (2007) [29]. This is one way to take advantage of the occurrence of eutrophication [29].

\section{Conclusions}

In the present work, composting technology was used in order to produce algal compost and extract that can be later used as organic amendment, fertilizer, or biostimulant for agricultural systems. It was shown that the obtained compost and extract were of good quality in terms of high nutrient and low toxic metal content. We examined their utilitarian properties in the germination tests on Lepidium sativum. The average length of plants fertilized with the compost and the extract was almost two times higher than in the control group. Also, the weight of wet biomass was about $50 \%$ higher in both experimental groups than in the control group. It was also found that the algal compost highly influenced the content of boron by 3.6 times, then for Fe (two times), Mn (28\%), and $\mathrm{Zn}$ (11\%) in the cultivated Lepidium sativum when compared with the control group.

On the basis of conducted experiments we can conclude that the utilization of renewable resources of 
algal biomass for agricultural and horticultural purposes could be beneficial for plant growth and, in addition, could help to improve physicochemical properties of the soil and improve seed yield.

\section{Acknowledgements}

This project was financed in the framework of a grant titled "Biologically active compounds in extracts from Baltic seaweeds" (2012/05/D/ST5/03379) from the National Science Centre, a grant titled "Innovative technology of seaweed extracts: components of fertilizers, feed, and cosmetics" (PBS/1/A1/2/2012) from the National Centre for Research and Development in Poland, and a project supported by the Wroclaw Centre of Biotechnology in a program of the Leading National Research Centre (KNOW) for 2014-18.

\section{References}

1. LOPEZ-MOSQUERA M.E., FERNANDEZ-LEMA E., VILLARES R., CORRAL R., ALONSO B., BLANCO C. Composting fish waste and seaweed to produce a fertilizer for use in organic agriculture. Proc. Environ. Sci. 9, 113, 2011.

2. KHANW., RAYIRATHU.P., SUBRAMANIANS., JITHESH M.N., RAYORATH P., HODGES D.M., CRITCHLEY A.T., CRAIGIE J.S., NORRIE J., PRITHIVIRAJ B. Seaweed extracts as biostimulants of plant growth and development. J. Plant Growth Regul. 28, 386, 2009.

3. MICHALAK I., CHOJNACKA K. Algal compost - toward sustainable fertilization. Rev. Inorg. Chem. 33, 161, 2013.

4. HAN W., CLARKE W., PRATT S. Composting of waste algae: A review. Waste Manage. 34, 1148, 2014.

5. DEDEREN L.H. T. Marine eutrophication in Europe: similarities and regional differences in appearance. In Vollenweider, R. A., Marchetti, R. \& Viviani R. (Eds.) Marine Coastal Eutrophication: Proceedings of an International Conference. Bologna, Italy, 21-24 March 1990, 663, 1992.

6. TRUUS K., VAHER M., TAURE I. Algal biomass from $\mathrm{Fu}$ cus vesiculosus (Phaeophyta): investigation of the mineral and alginate components. Proc. Estonian Acad. Sci. Chem. 50, 95, 2001

7. WINBERG P.C., DEMESTRE C., WILlIS S. Evaluating Microdictyon umbilicatum bloom biomass as an agricultural compost conditioner for native and commercial plants. Report to Shoalhaven City Council, 30p., 2011. Available: http://ro.uow.edu.au/cgi/viewcontent. cgi article $=1000 \&$ context $=$ smfc.

8. CRAIGIE J.S. Seaweed extract stimuli in plant science and agriculture. J. Appl. Phycol. 23, 371, 2010.

9. GAJKOWSKA-STEFANSKA L., GUBERSKI S., GUTOWSKI W., MAMAK Z., SZPERLINSKI Z. Laboratory analysis of water, wastewater and sewage sludge. Oficyna Wydawnicza Politechniki Warszawskiej, Warsaw, 2001 [In Polish].

10. EYRAS M.C., ROSTAGNO C.M., DEFOSSE G.E. Biological evaluation of seaweed composting. Compost Sci. Util. 6, 74, 1998.

11. HAQ T., KHAN F.A., BEGUM R., MUNSHI A.B. Bioconversion of drifted seaweed biomass into organic compost collected from the Karachi coast. Pak. J. Bot. 43, 3049, 2011.

12. ALVARADO D., BUITRAGO E., SOLE M., FRONTADO K. Experimental evaluation of a composted seaweed extract as microalgal culture media. Aquacult. Int. 16, 85, 2008.

13. CUOMO V., PERRETTI A., PALOMBA I., VERDE A., CUOMO A. Utilisation of Ulva rigida biomass in the Venice Lagoon (Italy): biotransformation in compost. J. Appl. Phycol. 7, 479, 1995.

14. ILLERA-VIVES M., SEOANE LABANDEIRA S., LOPEZ-MOSQUERA M. E. Production of compost from marine waste: evaluation of the product for use in ecological agriculture. J. Appl. Phycol. 25, 1395, 2013.

15. WOSNITZA T.M.A., BARRANTES J.G. Utilization of seaweed Ulva sp. in Paracas Bay (Peru): experimenting with compost. J. Appl. Phycol. 18, 27, 2005.

16. MAZE J., MORAND P., POTOKY P. Stabilisation of "green tides" Ulva by a method of composting with a view to pollution limitation. J. Appl. Phycol. 5, 183, 1993.

17. ORQUIN R., ABAD M., NOGUERA P., PUCHADES R., MAQUIEIRAA. Composting of Mediterranean seagrass and seaweed residues with yard waste for horticultural purposes. Acta Hort. 549, 29, 2001.

18. MEDINA E., PAREDES C., BUSTAMANTE M.A., MORAL R., MORENO-CASELLES J. Relationships between soil physico-chemical, chemical and biological properties in a soil amended with spent mushroom substrate. Geoderma. 173-174, 152, 2012.

19. FARIDULLAH NISAR Z., ALAM A., IRSHAD M., SABIR M.A. Distribution and evaluating phosphorus, potassium, calcium and magnesium in the fresh and composted poultry litter. Bul. J. Agricult. Sci. 20, 1368, 2014.

20. NKEMKA V.N., MURTO M. Evaluation of biogas production from seaweed in batch tests and in UASB reactors combined with the removal of heavy metals. J. Environ. Manage. 91, 1573, 2010.

21. TANG J., WANG M., ZHOU Q., NAGATA S. Improved composting of Undaria pinnatifida seaweed by inoculation with Halomonas and Gracilibacillus sp. isolated from marine environments. Bioresour. Technol. 102, 2925, 2011.

22. GRAVES R.E., HATTEMER G.M., STETTLERD., KRIDER J.N., CHAPMAN D. Composting. In National Engineering Handbook, Part 637-Environmental Engineering, United States Department of Agriculture, Chapter 2, 2000. Available at: ftp://ftp.wcc.nrcs.usda.gov/wntsc/AWM/neh637c2.pdf (last accessed 24 March 2014).

23. AHMED Y.M., SHALABY E.A. Effect of different seaweed extracts and compost on vegetative growth, yield and fruit quality of cucumber. J. Hort. Sci. Orn. Plants. 4, 235, 2012.

24. SOSNOWSKI J., JANKOWSKI K., WIŚNIEWSKAKADŻAJAN B., JANKOWSKA J., KOLCZAREK R. Effect of the extract from Ecklonia maxima on selected micro -and macroelements in aerial biomass of hybrid alfalfa. J. Elem. DOI: 10.5601/jelem.2014.19.1. 608, 209, 2014.

25. MOUSAVI S.R., GALAVI M., REZAEI M. The interaction of zinc with other elements in plants: a review. Int. J. Agricult. Crop. Sci. 4, 1881, 2012.

26. KABATA-PENDIAS A. Chromium, nickel and aluminium in environmental, ecological and methodical problems. Warsaw, PAN, 1993 [In Polish].

27. TUHY Ł., CHOJNACKA K., MICHALAK I., WITEKKROWIAK A. Algal extracts as a carrier of micronutrients - utilitarian properties of new formulations. In Kim, S.-K. \& Chojnacka, K. (Eds.) Marine Algae Extracts: Processes, Products, Applications. WILEY-VCH Verlag GmbH \& Co. KGaA, Weinheim, 467, 2015. 
28. KABIRINEJAD S., HOODAJI M. The effects of biosolid application on soil chemical properties and Zea mays nutrition. Int. J. Rec. Org. Waste Agricult. 1, 4, 2012: http://www. ijrowa.com/content/1/1/4.

29. CHARLIER R.H., MORAND P., FINKL C.W., THYS A. Green tides on the Brittany coasts. Environ. Res. Eng. Manage. 3, 52, 2007.

30. EYRAS M.C., DEFOSSE G.E., DELLATORRE F. Seaweed compost as an amendment for horticultural soils in Patagonia, Argentina. Compost. Sci. Util. 16, 119, 2008.
31. TANG J.C., WEI J.H., MAEDA K., KAWAI H., ZHOU Q., HOSOI-TANABE S., NAGATA S. Degradation of the seaweed Wakame (Undaria pinnatifida) by a composting process with the inoculation of Bacillus sp. HR6. Biocontrol Sci. 12, 47, 2007.

32. DE GUARDIA A., MALLARD P., TEGLIA C., MARIN A., LE PAPE C., LAUNAY M., BENOIST J.C., PETIOT C. Comparison of five organic wastes regarding their behavior during composting: Part 1, biodegradability, stabilization kinetics and temperature rise. Waste Manage. 30, 402, 2010. 